\title{
Erratum to: Change in urinary storage symptoms following treatment for female stress urinary incontinence
}

\author{
Zachary Panfili $^{1} \cdot$ William Parker $^{1} \cdot$ Alexander Gomelsky ${ }^{2} \cdot$ Priya Padmanabhan $^{1}$
}

Published online: 25 July 2016

(C) The International Urogynecological Association 2016

Erratum to: Int Urogynecol J (2016) 27:1169-1174

DOI: 10.1007/s00192-016-2951-6

Order of authors was incorrectly captured in the originally published article. The correct order is presented above.

The online version of the original article can be found under doi:10.1007 /s00192-016-2951-6.

\footnotetext{
Priya Padmanabhan

ppadmanabhan@kumc.edu

1 Department of Urology, University of Kansas Medical Center, 3901 Rainbow Blvd, Kansas City, KS 66160, USA

2 Department of Urology, Louisiana State University Health-Shreveport, 1501 Kings Highway, Shreveport, LA 71130, USA
} 